\title{
Virulence of Nano - Particle preparation of Entomopathogenic fungi and Entomopathogenic Bacteria against red palm weevil Rhynchophorus ferrugineus (Olivier) (Coleoptera: Curculionidae)
}

\author{
M.A. ABDEL-RAHEEM ${ }^{1}$, NAGLAA F. REYAD ${ }^{2,3}$, HUDA A. ALGHAMDI ${ }^{2}$ \\ ${ }^{1}$ Pests \& Plant Protection, Department, Agricultural and Biological Research Division, National \\ Research Centre, $33^{\text {rd }}$ ElBohouth St. - Dokki, Giza, Egypt \\ ${ }^{2}$ Biology Department, College of Science, King Khalid University, Abha, Saudi Arabia \\ ${ }^{3}$ Plant Protection Research Institute A. R. C. Dokki. Giza, Egypt
}

\begin{abstract}
Background: Rhynchophorus ferrugineus is one of the most severe pests on palm species, including date palms In Asia. Purpose: The purpose of the current study is to evaluate the virulence of bio efficacy of nano-particle of entomopathogenic fungi and entomopathogenic bacteria on red palm weevil, Rhynchophorus ferrugineus. Methods: Prepare concentrations of Fungal Spores and Silver Nano Particles were prepared from Metarhizium anisopliae, Beauveria bassiana, Verticillium lecanii and B. thuringiensis, B. subtilis. Results: M. anisopliae was the highest \% mortality (90\%), (95\%) and (77\%) against eggs, larvae and adults of $R$. ferrugineus, respectively when treated with bio synthesized or with fungal spores after seven days from treatment and the lowest $\%$ mortality was recorded when treated with $V$. lecanii.

Three concentrations, $\left(10^{3}, 10^{4}\right.$, and $\left.10^{5} \mathrm{CFU} / \mathrm{mL}\right)$, formulated as bacterial suspensions and bio-synthesized silver nanoparticles, (Ag NPs) were evaluated for their ability to inhibit egg hatch. The $10^{5} \mathrm{CFU} / \mathrm{mL}$ concentration, both as a bacterial suspension and formulated as Ag NPs, was tested for efficacy against 10 day-old larvae and adults. Egg hatch was significantly inhibited by all concentrations and formulations of B. subtilis and B. thuringiensis, and exhibited lethal concentrations for $50 \%$ mortality $\left(\mathrm{LC}_{50}\right)$ of $3.45 \times 10^{3}$ and $6.73 \times 10^{4} \mathrm{CFU} / \mathrm{mL}$, respectively. The percent mortality of larvae six days after treatment was $85 \%$ and $77 \%$ for B. thuringiensis and B. subtilis Ag NPs, respectively. The percent mortality of adults six days after treatment was $75 \%$ and $67 \%$ for B. thuringiensis and B. subtilis Ag NPs, respectively.

Conclusion: The bio control efficiency of Ag NPs synthesized by five isolates of $M$. anisopliae, B. bassiana, Bio Magic, Bio Power and Bio Catch on $R$. ferrugineus was proven to be effective through bio assay by spore suspension and bio synthesized silver nanoparticles. $M$. anisopliae had the highest efficiency on R. ferrugineus and was more effective than B. bassiana, Bio Magic, Bio Power and Bio Catch.

$B$. thuringiensis inhibited the hatching of $R$. ferrugineus, it is the highly effect than $B$. subtilis against all stages (eggs, Larvae and Adults) of $R$. ferrugineus. B. thuringiensis is the highly effect as a bio synthesized Ag NPs against larvae and adults of $R$. ferrugineus than bacterial suspensions. $B$. thuringiensis is the highest effect than $B$. subtilis as well bacterial suspensions or as a bio synthesized Ag NPs.
\end{abstract}

Keywords Virulence, Nano-particle, entomopathogenic fungi, entomopathogenic bacteria, Rhynchophorus ferrugineus.

To cite this article: ABDEL-RAHEEM M.A., REYAD NF, ALGHAMDI HA. Virulence of Nano - Particle preparation of Entomopathogenic fungi and Entomopathogenic Bacteria against red palm weevil Rhynchophorus ferrugineus (Olivier) (Coleoptera: Curculionidae). Rom Biotechnol Lett. 2020; 25(1): 1151-1159. DOI: 10.25083/rbl/25.1/1151.1159 


\section{Introduction}

Rhynchophorus ferrugineus is one of the most severe pests of palm species attacking date palms (Giblin-Davis, 2001). It develops within the trunk of date palm and subsequently destroys vascular system causing collapse then death of the tree. R. ferrugineus spreads in Europe Oceania, Africa and Asia. In Southeast Asia, R. ferrugineus has caused serious damage to coconuts, Giblin-Davis, (2001). In 1980s, it appeared in the Middle East. The first infestation in Jordan was in 1999, Khan and Gangapersad, (2001). The adults of $R$. ferrugineus are attracted to the damaged and dying parts of palm trees, Ferry and Gomez, (2002). Eggs are laid on the surface of the palm tree. The life stages are found in the same palm tree, Ferry and Gomez (2002), and Soroker, et al (2005). Natural parasites and pathogens of $R$. ferrugineus have been studied as biological control agents, Salama, et al (2004), Mohamed Abdel-Raheem (2019) and Shamseldean (2004). About 95 isolates of various microorganisms isolated from Rhynchophorus spp found in dead $R$. ferrugineus, only three isolates were entomopathogenic fungi, Salama, et al (2004) and Zaki and Abdel-Raheem (2010). M. anisopliae and $B$. bassiana were isolated from $R$. bilineatus in New Guinea and in Iran, Ghazavi and Avand-Faghih, (2002). Beauveria sp. was found associated with cocoons of $R$. ferrugineus, Shaiju-Simon, et al (2003). The entomopathogenic fungi are infecting the host by contact, penetrating through the insect cuticle. The host can be infected by direct treatment, by transmission of inoculum from treated insects, cadavers to untreated insects, or by the new generation of spores, Quesada-Moraga, et al (2004), Batta (2004), Ihara, et al (2003). The populations have been observed for various entomopathogenic fungi, e.g. B. bassiana, M. anisopliae and P. fumosoroseus), Quesada-Moraga, et al (2004), and Furlong and Pell (2001). Larvae and adults were contaminated with $B$. bassiana and $M$. anisopliae which \% mortality reached to 50-100, Glare, et al (2002).

Fungi, Bacteria, algae and plant extract are known to synthesize silver nanoparticles (Ag NPs), Borase (2014), Nisha, et al (2017), and Nadaf and Kanase (2016). Fungi such as Verticillium species are known to produce Ag NPs, Borase (2014), Praneehdevi, et al (2013) and Zonorodiam, (2016). The Bacillus genus contains key anatagonistic agents to many phytophagous insects (Salama et al 2004), many species of Bacillus have been used in biological control programs. Species of Bacillus synthesize proteins with insecticidal activity (Nicola et al 2015). Naji Mordi et al (2016) isolated and characterized Bacillus species from dead red palm weevil adults. NPs using microbes have advantages like being clean, non-toxic, eco-friendly, and it is also possible at ambient temperature and pressure. Recently, research efforts point out the potential of the green synthesis of metal NPs, chiefly Ag NPs, for use against a wide spectrum of noxious pest species either in the laboratory or in the field. For example, Jayaseelan et al (2011) reported that Ag NPs synthesized by leaf aqueous extract of Tinospora cordifolia (Thunb.) caused complete mortality of the head louse, P. humanus capitis De Geer adults after $1 \mathrm{~h}$ of exposure at $25 \mathrm{mg} / \mathrm{l}$. Ag NPs was negatively influenced the growth (i.e., larval weight and period of development, pupal weight, and adult weight) of both species as a result of the physiological changes in the body of the insects due to the presence of NPs (Yasur and Usha Rani 2015). Ag NPs synthesized by extracellular filtrate of the entomopathogenic fungus Trichoderma harzianum Rifai (Hypocreales: Hypocreaceae) resulted in 92, 96, and $100 \%$ mortality of $1^{\text {st }}, 2^{\text {nd }}$, and $3^{\text {rd }} 4^{\text {th }}$ instar larvae or pupae of $A$. aegypti, respectively, at $0.25 \%$ concentration after $24 \mathrm{~h}$ of exposure (Sundaravadivelan and Padmanabhan 2014).

The aim of this study was to evaluate the virulence of bio efficacy of Nano-particle of entomopathogenic fungi as Fungal Spores and Silver Nano Particles and Nano-particle preparation of entomopathogenic bacteria on $R$. ferrugineus (eggs, larvae and adults).

\section{Materials and Methods}

\section{Insect host}

Palm trees, Phoenix dactylifera were examined. Many stages of $R$. ferrugineus such as larvae, cocoons and adults were collected from damaged trees from Al-Ahsa, Saudi Arabia. Samples were collected and transferred to the laboratory of Biological Science Department, Faculty of Science, University, Jeddah, Saudi Arabia and examined carefully.

\section{Insect rearing}

$R$. ferrugineus colony was reared in the laboratory of Biological Science Department, Faculty of Science, University, Jeddah, Saudi Arabia on sugarcane as both food and oviposition substrate, Adults was put to mate and oviposit in groups of five pairs put on a substrate of moist sugar cane sawdust. From the $1^{\text {st }}$ larval stage to adult emergence, $R$. ferrugineus were reared individually at $27 \pm 2^{\circ} \mathrm{C}$. For egg harvesting, the adults of both sexes were kept on sugarcane sawdust. The eggs were collected every 2 days. Newly hatched adults, males and females, were placed in rearing boxes with sugarcane to eat. The first eggs are laid after two to three days, and the high number of eggs per female has been counted after sixteen days. After three weeks, the ovipositing females were placed in new boxes daily with fresh sugarcane and one day old eggs were collected for treatments. We collected the larvae after ten days old and reared individually and fed on amounts of sugar cane.

\section{Entomopathogenic Fungi}

\section{Egyptian Isolates}

M. anisopliae isolated from larvae and adults of S. ocellatella and Beauveria bassiana (Balsamo) Vuillemin, isolated from Cassida vittata (Abdel-Raheem, 2005), were grown on Peptone media (10 g Peptone, $40 \mathrm{~g}$ Dextrose, $2 \mathrm{~g}$ yeast extract, $15 \mathrm{~g} \mathrm{Agar}$ and $500 \mathrm{ml}$. Chloramphenicol). The media was autoclaved at $120^{\circ} \mathrm{C}$ for 20 minutes, and poured into Petri- dishes $(10 \mathrm{~cm}$ diameter x $1.5 \mathrm{~cm})$. Then 
the incubated the fungi were kept at $24 \pm 2{ }^{\circ} \mathrm{C}$ and $65 \pm 5 \%$ $\mathrm{RH}$. The fungal isolates were re-cultured every 14-30 days and kept at $4^{\circ} \mathrm{C}$.

\section{Commercial Indian Compounds}

The concentration of entomopathogenic fungi, Bio Magic (M. anisopliae) Bio Power (B. bassiana) and Bio Catch (V. lecanii) was $1 \times 10^{9}$ spores / ml.

\section{Concentrations Preparing}

Spores harvested by rising with sterilized water and added $0.5 \%$ Tween 80 from culture Peptone media 14 day old. The suspensions were filtered through cheese cloth to reduce mycelium clumping. The spores were counted in the suspension using a Haemocytometer $(0.1 \mathrm{~mm} \mathrm{x}$ $0.0025 \mathrm{~mm}^{2}$ ). The concentrations used $1 \times 10^{9}$ spores $/ \mathrm{ml}$ from all entomopathogenic fungi. The grown fungal cultures were centrifuged at $12000 \mathrm{rpm}$ fungal for $30 \mathrm{~min}$ at $25^{\circ} \mathrm{C}$ and the supernatant was used for the synthesis of $\mathrm{Ag}$ NPs.

\section{Silver nanoparticles bio synthesis}

Silver nanoparticles were synthesized by using $50 \mathrm{ml}$

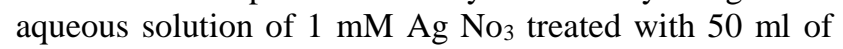
fungi culture supernatant in a $250 \mathrm{ml}$ conical flask and the $\mathrm{PH}$ was adjusted to 8.5 . The whole mixture was incubated at $40^{\circ} \mathrm{C}$ at $200 \mathrm{rpm}$ for 7 days under dark condition. The control was maintained without adding the culture supernatant to the solution of $\mathrm{Ag} \mathrm{No}_{3}$.

\section{Bioassay procedure}

M. anisopliae, B. bassiana, Bio Magic, Bio Power, and Bio Catch were tested at concentrations (1 x $10^{9}$ spores/ml to contaminate the eggs, larval and adults of $R$. ferrugineus 100 Eggs, larvae and adults were used for each treatment, divided into four groups each of twenty five eggs, larvae and adults placed in Petridishes, one individual/dish. The fungi were applied in a suspension in the control group, treated with sterilized water, and kept at $27 \pm 2{ }^{\circ} \mathrm{C}$ and $65 \pm 5 \%$ R.H. The mortality of $R$. ferrugineus was observed after seven days.

\section{Bio assay studies}

$R$. ferrugineus was placed in sterile Petri dishes having food and sterile filter paper. The nanoparticle solution was sprinkled over the filter paper. The filter paper was allowed to air dry aseptically and incubated at $27 \pm 2{ }^{\circ} \mathrm{C}$ at for three days. The experiment was replicated thrice. Mortality was taken five days after the treatment and \% mortality was calculated.

\section{B. thuringiensis and B. subtilis Concentrations Preparing}

To prepare B. subtilis and B. thuringiensis for the bioassays, colonies of each species were grown overnight in $150 \mathrm{~mL}$ of nutrient broth at $32^{\circ} \mathrm{C}$ with constant agitation $(120 \mathrm{rpm})$. The harvested cells were rinsed twice with Ringer's solution and centrifuged for 5 minutes at 1,400 rpm between rinses, Bernhard Winkler et al 2016. The cell suspensions were diluted to obtain $10^{5}, 10^{4}$, and $10^{3} \mathrm{CFU} / \mathrm{mL}$. The concentration of each Bacillus species used in the biosynthesis of Ag NPs was $10^{5} \mathrm{CFU} / \mathrm{ml}$. Mature cultures of each Bacillus species was centrifuged at $12,000 \mathrm{rpm}$ for 30 minutes at $25^{\circ} \mathrm{C}$. The supernatant was used in the synthesis of the Ag NPs.

The Ag NPs were synthesized by combining $50 \mathrm{~mL}$ aqueous solution of $1 \mathrm{mM} \mathrm{Ag} \mathrm{NO}$ with $50 \mathrm{~mL}$ of Bacillus culture supernatant. The mixture was incubated at $40^{\circ} \mathrm{C}$ with agitation (200 rpm) for 7 days under dark conditions. Control particles were created without adding the culture supernatant to the $\mathrm{Ag} \mathrm{NO}_{3}$ solution.

\section{The bioassay description}

To assay eggs, 10 eggs were placed on a filter paper in a petri dish. The eggs were then sprayed with $2 \mathrm{~mL}$ of the appropriate cell suspension. The petri dishes were sealed with Parafilm ${ }^{\circledR}$ (Kaakeh 2005), and placed at $25^{\circ} \mathrm{C}$ and $75 \%$ R.H. The number of eggs hatching was counted daily for six days. As well as the control, in which eggs were placed in the presence of distilled water only.

To assay the larvae, $1 \mathrm{~mL}$ of $10^{5} \mathrm{CFU} / \mathrm{mL}$ suspension of each Bacillus species or $1 \mathrm{~mL}$ of Ringer's solution (control) was sprayed on a piece of apple for larvae in plastic cups individually and adult with shredded sugarcane pieces $(3 \times 3 \mathrm{~cm})$. Larvae were placed in the container with the apple piece and held at $25^{\circ} \mathrm{C}$ and $75 \%$ R.H. The larvae were checked daily for 10 days, and the number that had died recorded. The nanoparticle solution was sprinkled over the filter paper, and the filter paper was allowed to air dry under aseptic conditions. The treated filter papers were placed in with sugarcane sawdust (10 gm / dish) for food with adds and change food when it need. The petri dishes containing the weevil (Eggs, Larvae and Adults) were placed at $27 \pm 2^{\circ} \mathrm{C}$ for 6 days. Morality was assessed 6 days after treatment and percent mortality calculated. For control treatment the individuals were immersed in distilled water.

\section{Results and Discussion}

The efficacy of nanoparticle preparations of Metarhizium anisopliae, Beauveria bassiana, and Verticillium lecanii against eggs, larvae, and adults of the red palm weevil.

Table 1 shows that the results of the eggs of $R$. ferrugineus which were treated with $M$. anisopliae, B. bassiana, Bio Magic, Bio Power and Bio Catch as fungal Spores and Silver nano particles. After six days of treatment, the petri dishes plates were observed and the result was $90 \%$ mortality of $R$. ferrugineus eggs. Additionally, white, green and metallic muscardine were found on the dead eggs. The $\%$ mortality after six days, from treated subjects, recorded $80,73,65,60$, and $45 \%$ by infection with fungal spores from M. anisopliae, B. bassiana, Bio Magic, Bio Power and Bio Catch, respectively. Furthermore, the $\%$ mortality after six days from treated subjects recorded $90,84,73,70$, and $58 \%$ by infection with bio synthesized Ag NPs from M. anisopliae, B. bassiana, Bio Magic, Bio Power and Bio Catch, respectively. $M$. anisopliae was the highest \% mortality (90\%) on the eggs of $R$. ferrugineus when treated with bio synthesized or with fungal spores after six days from treatment and the lowest $\%$ mortality was $(58 \%)$ when treated with Bio Catch. The results according with Abdel-Rahman and 
Abdel-Raheem, (2018), Abdel-Raheem, (2019), Mohamed Abdel-Raheem, et al ( 2016, 2018 \& 2019), Abdel-Raheem, (2011), Abdel-Raheem, et al (2009, 2011, 2013, $\left.2016^{\mathrm{a}, \mathrm{b}}\right)$, Abdel-Raheem and Lamya Ahmed Al-Keridis (2017),
Mohamed Abdel-Raheem (2019), and Salem, et al (2016), mentioned when eggs were exposed to $M$. anisopliae spores, the total mortality of eggs and emerged larvae were reduced in comparison with the control group.

Table 1. Bio efficacy of entomopathogenic fungi on the eggs of $R$. ferrugineus using spore suspension and bio synthesized silver nanoparticles

\begin{tabular}{|c|c|c|}
\hline Entomopathogenic fungi & \multicolumn{2}{|c|}{ Treated with } \\
\cline { 2 - 3 } & $\begin{array}{c}\text { Fungal spores } \\
\text { (Mean } \pm \text { S.E) }\end{array}$ & $\begin{array}{c}\text { Bio synthesized Ag NPs } \\
\text { (Mean } \pm \text { S.E) }\end{array}$ \\
\hline M. anisopliae & $80.0 \pm 1.20$ & $90.0 \pm 2.10$ \\
\hline B. bassiana & $73.0 \pm 1.00$ & $84.0 \pm 1.30$ \\
\hline Bio Magic & $65.0 \pm 0.20$ & $73.0 \pm 0.10$ \\
\hline Bio Power & $60.0 \pm 3.10$ & $70.0 \pm 0.20$ \\
\hline Bio Catch & $45.0 \pm 0.20$ & $58.0 \pm 1.20$ \\
\hline Control & 6.0 & 1.98 \\
\hline S.E $(\mathrm{m})$ & 1.14 & \\
\hline
\end{tabular}

Table 2 shows that the $4^{\text {th }}$ larvae of $R$. ferrugineus were treated with $M$. anisopliae, B. bassiana, Bio Magic, Bio Power and Bio Catch as fungal Spores and Silver nano particles. After six days of treatment, the petri dishes plates showed up to $90 \%$ mortality of $R$. ferrugineus larvae. Also, white, green and metallic muscardine were found on the dead larvae. The $\%$ mortality after six days recorded 84,75 , 71,65 , and $55 \%$ by infection with fungal spores from M. anisopliae, B. bassiana, Bio Magic, Bio Power and Bio Catch, respectively. Furthermore, the $\%$ mortality after six days recorded $95,87,77,73$, and $60 \%$ by infection with bio synthesized Ag NPs from M. anisopliae, B. bassiana,
Bio Magic, Bio Power and Bio Catch, respectively. M. anisopliae was the highest \% mortality (95\%) against the larvae of $R$. ferrugineus when treated with bio synthesized or with fungal spores after six days and the lowest \% mortality was $(60 \%)$ when treated with Bio Catch, V. lecanii. The results according with Ekesi, (2001), Tefera, and Pringle, (2003) and Thomas, et al (1997), mentioned the bio efficacy of $M$. anisopliae in all stages of $R$. ferrugineus caused up to 48 to $95 \%$ mortality of adult and larvae.

Table 2. Bio efficacy of entomopathogenic fungi on the 4th larvae of R. ferrugineus using spore suspension and bio synthesized silver nanoparticles

\begin{tabular}{|c|c|c|}
\hline \multirow{2}{*}{ Entomopathogenic fungi } & \multicolumn{2}{|c|}{ Treated with } \\
\cline { 2 - 3 } & $\begin{array}{c}\text { Fungal spores } \\
\text { (Mean } \pm \text { S.E) }\end{array}$ & $\begin{array}{c}\text { Bio synthesized Ag NPs } \\
\text { (Mean } \pm \text { S.E) }\end{array}$ \\
\hline M. anisopliae & $84.0 \pm 2.10$ & $95.0 \pm 2.30$ \\
\hline B. bassiana & $75.0 \pm 2.12$ & $87.0 \pm 2.22$ \\
\hline Bio Magic & $71.0 \pm 2.20$ & $77.0 \pm 1.10$ \\
\hline Bio Power & $65.0 \pm 1.10$ & $73.0 \pm 1.20$ \\
\hline Bio Catch & $55.0 \pm 0.10$ & $60.0 \pm 1.00$ \\
\hline Control & 6.2 & 7.3 \\
\hline S.E $(\mathrm{m})$ & 2.10 & 3.00 \\
\hline
\end{tabular}

Table 3 shows that the adults of $R$. ferrugineus were treated with $M$. anisopliae, B. bassiana, Bio Magic, Bio Power and Bio Catch as fungal Spores and Silver nano particles.

After six days of treatment, the petri dishes plates were observed and the parentage of mortality of $R$. ferrugineus adults was $77 \%$. Also, white, green and metallic muscardine were found on the dead adults. The $\%$ mortality after six days recorded $65,61,56,52$, and $35 \%$ by infection with fungal spores from $M$. anisopliae, B. bassiana, Bio Magic, Bio Power and Bio Catch, respectively. Moreover, the $\%$ mortality after six days of treatment recorded $77,70,63,55$, and $48 \%$ by infection with bio synthesized Ag NPs from $M$. anisopliae, B. bassiana, Bio Magic, Bio Power and Bio Catch, respectively. M. anisopliae was the highest \% mortality (77\%) against the adults of $R$. ferrugineus when treated with bio synthesized or with fungal spores after six days and the lowest \% mortality was $(48 \%)$ when it treated with Bio Catch. Gothandapani et al (2015) and Ownley, et al (2008), stated that the entomopathogenic fungi are ecofriendly and have the bio control quality against insect pests. Biology synthesis of silver nanoparticles (Ag NPs) has given a new scope for a non-toxic environment $(\mathrm{Hu}$, et al (2006), Moonjung, et al (2010), Navrotsky, (2000), Prakash et al (2013), Subha, et al (2017), Deeba Kamil, 
(2017), and Gindin, et al (2006). Monir M. El Husseini, (2019), treated the adults and larvae of $R$. ferrugineus with conidiospores of entomopathogenic fungus Beauveria bassiana the mortality reached to $100 \%$ mortality.

Table 3. Bio efficacy of entomopathogenic fungi on the adults of $R$. ferrugineus using spore suspension and bio synthesized silver nanoparticles

\begin{tabular}{|c|c|c|}
\hline \multirow{2}{*}{ Entomopathogenic fungi } & \multicolumn{2}{|c|}{ Treated with } \\
\cline { 2 - 3 } & $\begin{array}{c}\text { Fungal spores } \\
\text { (Mean } \pm \text { S.E) }\end{array}$ & $\begin{array}{c}\text { Bio synthesized Ag NPs } \\
\text { (Mean } \pm \text { S.E) }\end{array}$ \\
\hline M. anisopliae & $65.0 \pm 2.00$ & $77.0 \pm 1.30$ \\
\hline B. bassiana & $61.0 \pm 1.20$ & $70.0 \pm 2.10$ \\
\hline Bio Magic & $56.0 \pm 2.20$ & $63.0 \pm 0.10$ \\
\hline Bio Power & $52.0 \pm 1.20$ & $55.0 \pm 3.20$ \\
\hline Bio Catch & $35.0 \pm 0.00$ & $48.0 \pm 0.20$ \\
\hline Control & 7.0 & 8.0 \\
\hline S.E $(\mathrm{m})$ & 1.94 & 2.90 \\
\hline
\end{tabular}

The efficacy of nanoparticle preparations of Bacillus subtilis, $B$. thuringiensis against eggs, larvae, and adults of the red palm weevil

The mean number of unhatched eggs occurred at the highest concentration of each Bacillus species (Table 4). The highest concentration of $B$. thuringiensis resulted in a mean of $9.5( \pm 0.4)$ unhatched eggs, and the highest concentration of B. subtilis, a mean of $7.5( \pm 0.2)$ unhatched eggs. Probit analysis revealed that the $\mathrm{LC}_{50}$ or the Lethal Concentration to cause $50 \%$ mortality was greatest for
B. thuringiensis while the $\mathrm{LC}_{90}$ was greatest for B. subtilis. Using of pathogens on $R$. ferrugineus showed more capacity in decreasing $R$. ferrugineus populations, Dembilio and Jacas, 2012 and Francardi et al, 2012. Bacteria collected from larvae and used for anti-hatching activity, Salama et al, 2004 and Butera et al, 2012. B. subtilis was the lowest $\mathrm{LC}_{50}$ and mortality at the highest concentration. B. thuringiensis was the highest inhibit of hatching eggs, Salama et al, 2004.

Table 4. Average number and Probit analysis of un hatching eggs of $R$. ferrugineus

\begin{tabular}{|c|c|c|c|c|c|c|c|c|}
\hline \multirow[t]{3}{*}{ Isolates } & \multicolumn{8}{|c|}{ Inhibition on hatching (mean \pm SE) } \\
\hline & \multicolumn{8}{|c|}{ concentration $(\mathrm{CFU} / \mathrm{mL})$} \\
\hline & Control & $10^{3}$ & $10^{4}$ & $10^{5}$ & $\begin{array}{c}\text { Slope } \\
\pm \text { S.E. }\end{array}$ & $\begin{array}{c}\chi^{2} \\
\text { (P value) }\end{array}$ & $\begin{array}{c}\mathrm{LC}_{50} \\
(\mathrm{CFU} / \mathrm{mL}) \\
(95 \% \mathrm{FL})\end{array}$ & $\begin{array}{c}\mathrm{LC}_{90} \\
(\mathrm{CFU} / \mathrm{mL}) \\
(95 \% \mathrm{FL})\end{array}$ \\
\hline B. subtilis & $2.0 \pm 0.2$ & $\begin{array}{c}4.4 \pm \\
0.3\end{array}$ & $\begin{array}{c}7.0 \\
\pm 0.0\end{array}$ & $\begin{array}{c}7.5 \\
\pm 0.2\end{array}$ & $\begin{array}{c}0.3670 \pm 0.1 \\
227^{*}\end{array}$ & $\begin{array}{c}1.923 \\
(0.496)\end{array}$ & $\begin{array}{c}6.73 \times 10^{4} \\
\left(5.87 \times 10^{3}-\right. \\
\left.1.58 \times 10^{6}\right)\end{array}$ & $\begin{array}{c}2.68 \times 10^{8} \\
\left(4.98 \times 10^{6}-\right. \\
\left.6.77 \times 10^{10}\right)\end{array}$ \\
\hline B. thuringiensis & $1.2 \pm 0.2$ & $\begin{array}{l}5.40 \\
\pm 0.7\end{array}$ & $\begin{array}{c}8.0 \\
\pm 0.0\end{array}$ & $\begin{array}{c}9.5 \\
\pm 0.4\end{array}$ & $\begin{array}{c}0.2538 \pm 0.1 \\
220^{*}\end{array}$ & $\begin{array}{c}0.124 \\
(0.954)\end{array}$ & $\begin{array}{c}3.45 \times 10^{3} \\
\left(1.69 \times 10^{2}-\right. \\
\left.7.25 \times 10^{4}\right)\end{array}$ & $\begin{array}{c}6.59 \times 10^{8} \\
\left(4.28 \times 10^{6}-\right. \\
\left.7.89 \times 10^{9}\right)\end{array}$ \\
\hline
\end{tabular}

A significant difference between treated and control larvae were by using $B$. thuringiensis in (Table 5). The highest concentration of $B$. thuringiensis resulted in a mean of $2.37( \pm 0.27)$ larvae and the highest concentration of B. subtilis, a mean of $2.02( \pm 1.00)$ larvae. The total died of larvae treated with the highest concentration of B. thuringiensis resulted in 8 while the total died of larvae treated with the highest concentration of B. subtilis was 7 .

Table 5. Treated the neonate larvae of $R$. ferrugineus with concentration $10^{5} \mathrm{CFU} / \mathrm{mL}$ from $B$. subtilis and B. thuringiensis

\begin{tabular}{|c|c|c|c|c|c|}
\hline \multirow{2}{*}{ Isolates } & \multicolumn{2}{|c|}{ Mean \pm SE } & \multicolumn{2}{c|}{ Total died larvae } & \multirow{2}{*}{ P value* } \\
\cline { 2 - 5 } & Control & Treated & Control & Treated & \\
\hline B. subtilis & 0.00 & $2.02 \pm 1.00$ & 0 & 7 & 0.0127 \\
\hline B. thuringiensis & 0.00 & $2.37 \pm 0.27$ & 0 & 8 & 0.1892 \\
\hline
\end{tabular}

A significant difference between treated and control adults were by using B. thuringiensis in (Table 6). The highest concentration of $B$. thuringiensis resulted in a mean of $2.25( \pm 0.22)$ and the highest concentration of B. subtilis, a mean of $1.01( \pm 2.00)$. The total died of a treated with the highest concentration of $B$. thuringiensis resulted in 7 while the total died of adults treated with the highest concentration of B. subtilis was 5 . 
Table 6. Treated adults of $R$. ferrugineus with concentration $10^{5} \mathrm{CFU} / \mathrm{mL}$ from $B$. subtilis and B. thuringiensis

\begin{tabular}{|c|c|c|c|c|c|}
\hline \multirow{2}{*}{ Isolates } & \multicolumn{2}{|c|}{ Mean \pm SE } & \multicolumn{2}{c|}{ Total died adults } & \multirow{2}{*}{ P value* } \\
\cline { 2 - 5 } & Control & Treated & Control & Treated & \\
\hline B. subtilis & 0.00 & $1.01 \pm 2.00$ & 0 & 5 & 0.0116 \\
\hline B. thuringiensis & 0.00 & $2.25 \pm 0.22$ & 0 & 7 & 0.1990 \\
\hline
\end{tabular}

Differences in mortality for larvae treated with bacterial suspensions or with biosynthesized Ag NPs were observed for both species of Bacillus (Table 5). The biosynthesized Ag NPs treatments had higher mortalities than that found with the bacterial suspensions. B. thuringiensis caused the highest larval mortality, regardless of formulation (Table 4). Both Bacillus species caused greater larval mortality than the controls (Table 7).

After six days of treatment, the petri dishes plates were observed was $74 \%$ mortality of $R$. ferrugineus adults.
The $\%$ mortality after six days from treated recorded $74 \%$ and $67 \%$ by infection with bacterial suspensions from B. thuringiensis and B. subtilis, respectively. Also, the \% mortality after six days from treated recorded 85 and $77 \%$ by infection with bio synthesized Ag NPs from B. thuringiensis and B. subtilis, respectively. B. thuringiensis was the highest $\%$ mortality $(85 \%)$ against the larvae of $R$. ferrugineus when treated with bio synthesized or with bacterial suspensions after six days and the lowest \% mortality (77\%) when it treated with B. subtilis.

Table 7. Efficacy of $B$. thuringiensis and B. subtilis against the larvae of $R$. ferrugineus using bacterial suspensions and bio synthesized silver nanoparticles

\begin{tabular}{|c|c|c|}
\hline Entomopathogenic bacteria & \multicolumn{2}{|c|}{ Treated with } \\
\cline { 2 - 3 } & $\begin{array}{c}\text { bacterial suspensions } \\
\text { (Mean percent mortality } \pm \text { S.E) }\end{array}$ & $\begin{array}{c}\text { Bio synthesized Ag NPs } \\
\text { (Mean percent mortality } \pm \text { S.E) }\end{array}$ \\
\hline B. thuringiensis & $74.0 \pm 1.41$ & $85.0 \pm 2.20$ \\
\hline B. subtilis & $67.0 \pm 1.22$ & $77.0 \pm 2.33$ \\
\hline Control & 6.7 & 7.1 \\
\hline S.E(m) & 2.2 & 2.90 \\
\hline
\end{tabular}

The efficacy of the Ag NPs against adult red palm weevils was greater than that from the bacterial suspensions (Table 8). Again, B. thuringiensis imparted more mortality than B. subtilis, regardless of formulation. The mortality imparted by either Bacillus species was greater than the controls.

After six days of treatment, the petri dishes plates were observed was $61 \%$ mortality of $R$. ferrugineus adults. The $\%$ mortality after six days from treated recorded $61 \%$ and $55 \%$ by infection with bacterial suspensions from B. thuringiensis and B. subtilis, respectively. Also, the \% mortality after six days from treated recorded 75 and $67 \%$ by infection with bio synthesized Ag NPs from B. thuringiensis and B. subtilis, respectively. B. thuringiensis was the highest $\%$ mortality $(75 \%)$ against the adults of $R$. ferrugineus when treated with bio synthesized or with bacterial suspensions after six days and the lowest \% mortality $(67 \%)$ when it treated with $B$. subtilis

Table 8. Efficacy of B. thuringiensis and B. subtilis against the adults of R. ferrugineus using bacterial suspension and bio synthesized silver nanoparticles

\begin{tabular}{|c|c|c|}
\hline Entomopathogenic bacterial & \multicolumn{2}{|c|}{ Treated with } \\
\cline { 2 - 3 } & $\begin{array}{c}\text { bacterial suspensions } \\
\text { (Mean percent mortality } \pm \text { S.E) }\end{array}$ & $\begin{array}{c}\text { Bio synthesized Ag NPs } \\
\text { (Mean percent mortality } \pm \text { S.E) }\end{array}$ \\
\hline B. thuringiensis & $61.0 \pm 2.10$ & $75.0 \pm 1.40$ \\
\hline B. subtilis & $55.0 \pm 1.10$ & $67.0 \pm 2.30$ \\
\hline Control & 7.2 & 8.2 \\
\hline S.E $(\mathrm{m})$ & 1.95 & 2.97 \\
\hline
\end{tabular}

\section{Conclusion}

The bio control efficiency of Ag NPs synthesized by five isolates of $M$. anisopliae, B. bassiana, Bio Magic, Bio Power and Bio Catch on $R$. ferrugineus was proven to be effective through bio assay by spore suspension and bio synthesized silver nanoparticles. M. anisopliae had the highest efficiency on $R$. ferrugineus and was more effective than B. bassiana, Bio Magic, Bio Power and Bio Catch.

$B$. thuringiensis inhibited the hatching of $R$. ferrugineus, it is the highly effect than B. subtilis against all stages (eggs, Larvae and Adults) of $R$. ferrugineus. B. thuringiensis is the highly effect as a bio synthesized Ag NPs against larvae and adults of $R$. ferrugineus than bacterial suspensions. 
B. thuringiensis is the highest effect than B. subtilis as well bacterial suspensions or as a bio synthesized Ag NPs.

The author's stated that for control R. ferrugineus by entomopathogenic fungi or entomopathogenic bacteria you should use $M$. anisopliae, B. bassiana as a bio synthesized Ag NPs or B. thuringiensis as a bio synthesized Ag NPs because proven the highly virulence against $R$. ferrugineus in all stages.

\section{Declarations}

\section{Acknowledgement}

The authors extend their appreciation to the Deanship of Scientific Research at King Khalid University, Abha, KSA for funding this study through Research Groups Program under grant number (R.G.P.1/78/40).

\section{Funding}

The study was supported by King Khalid University, Abha, KSA for funding this study through Research Groups Program under grant number (R.G.P.1/78/40).

\section{Authors Contribution}

The authors declare that this work was done by the authors named in this article and all liabilities pertaining to claims relating to the content of this article will be borne by them.

\section{Competing interests} interest.

The authors declare that they have no competing

\section{References}

1. ABDEL-RAHEEM, MA (2005). Possibility of Using the Entomopathogenic Fungi Beauveria bassiana and Metarhizium anisopliae for controlling the Sugar-Beet Insects Cassida vittata Vill. and Scrobipalpa ocellatella Boh. in Egypt, Ph.D. Faculty of Agriculture, Cairo University, Cairo., P 86.

2. ABDEL-RAHEEM, MA (2011). Impact of Entomopathogenic Fungi on Cabbage Aphids, Brevicoryne brassica L. in Egypt. Bull. NRC, 36(1): 53-62.

3. ABDEL-RAHEEM, MA (2013). Susceptibility of the red palm weevil, Rhynchophorus ferrugineus Olivier to some Entomopathogenic Fungi Bull. NRC, 2013, 38(1):69 -82.

4. ABDEL-RAHEEM, MA (2019). Pathogenicity Comparative of Some Egyptian Isolates and Commercial Indians Compounds of Entomopathogenic Fungi Against Some Insect Pests. Plant Archives, 19, supplement (1):1061-1068, 2019

5. ABDEL-RAHEEM, MA and LAMYA AHMED AL-KERIDIS A (2017). Virulence of three Entomopathogenic Fungi against White fly, Bemisia tabaci (Genn.) (Hemiptera: Aleyrodidae) in Tomato Crop. Journal of Entomology, 14(4):155-159.

6. ABDEL-RAHEEM, MA, SABRY, KH, ZAKIA A RAGAB (2009). Effect of different fertilization rates on control of Bemisia tabaci (Genn.) by Virticillium lecanii and Beauveria bassiana in potato crop. J. Biol. Pest control, 19(2), 129-133.
7. ABDEL-RAHEEM, M A; I.A. ISMAIL; NA FARAG, RS ABDEL-RAHMAN and H H ELBEHERY (2016 ${ }^{\mathrm{a}}$ ). Isolates, Virulence of two Entomopathogenic Fungi as biological control agent on sugar beet fly, Pegomyia mixta in Egypt. Der Pharma Chemica, 8(18):132-138.

8. ABDEL-RAHEEM, MA; NAGLAA F REYAD; AL-SHURAYM, LAILA A and ABDEL-RAHMAN, IE $\left(2016^{\mathrm{b}}\right)$. Nano Entomopathogenic Fungi As biological Control Agents on Cabbage Worm, Pieris rapae L. (Lepidoptera: Pieridae). Der Pharma Chemica, 8(16):93-97.

9. ABDEL-RAHMAN, IE, ABDEL-RAHEEM, MA (2018). Using entomopathogenic fungi as bio agents control on the red palm weevil, Rhynchophorus ferrugineus (Olivier) (Coleoptera: Curculionidae), Journal of Entomology and Zoology Studies; 6(6): 387-390. http://www.entomoljournal.com/archives/2018/ vol6issue6/PartG/6-5-342-932.pdf

10. BATTA, YA (2004). Control of rice weevil (Sitophilus oryzae L., Coleoptera: Curculionidae) with various formulations of Metarhizium anisopliae. Crop Prot., 23:103-108.

11. BERNHARD WINKLER, DAVID REINEKE, PAUL PHILIP HEINISCH, FLORIAN SCHÖNHOFF, CHRISTOPH HUBER, ALEXANDER KADNER, LARS ENGLBERGER and THIERRY CARREL (2016). Graft preservation solutions in cardiovascular surgery, Interactive CardioVascular and Thoracic Surgery, 23(2):300-309, https://doi.org/10.1093/icvts/ ivw056

12. BORASE, HP, SAHMKE, B.K., SALUMKHE, RB, PATIL, CD, HALLSWORTH,J E , KIM, BS, PATIL, S.V. (2014). Plant extract: a promising biomatrix for ecofriendly, controlled synthesis for silver nanoparticles. Appl. Biochem Biotech, 173.1.

13. BUTERA G, FERRARO C, COLAZZA S, ALONZO G, QUATRINI P (2012). The culturable bacterial community of frass produced by larvae of Rhynchophorus ferrugineus Olivier (Coleoptera: Curculionidae) in the Canary island date palm. Lett Appl Microbiol 54(6):530-536.

14. DEEBA KAMIL, T PRAMEELADEVI, SANKAR GANESH, NPRABHAKARAN, R NRESHKUMAR, SHAN P THOMAS (2017). Green Synthesis of Silver nano particles by entomopathogenic fungus Beauveria bassiana and their bio efficacy against mustard aphid (Lipaphis erysimi kal.), Indian Journal of experimental Biology, 55: 555-561.

15. DEMBILIO O, JACAS JA (2012). Bio-ecology and integrated management of the red palm weevil, Rhynchophorus ferrugineus (Coleoptera: Curculionidae), in the region of Valencia (Spain). Hell Plant Prot J 5: 1-12

16. EKESI, S (2001). Pathogenicity and antifeedant activity of entomopathogenic hyphomycetes to the cowpea leaf beetle, Ootheca mutabilis Shalberg. Insect Sci. Appl. 21:55-60.

17. FERRY, M, GOMEZ, S (2002). The red palm weevil in the Mediterranean area. Palms 2002, 46. 
18. FINNEY DJ (1971). Probit Analysis (3rd edition). Cambridge University Press, Cambridge, UK.

19. FRANCARDI V, BENVENUTI C, ROVERSI PF, RUMINE P, BARZANTI G (2012). Entomopathogenicity of Beauveria bassiana (Bals.) Vuill. and Metarhizium anisopliae (Metsch.) Sorokin isolated from different sources in the control of Rhynchophorus ferrugineus (Olivier) (Coleoptera Curculionidae). REDIA 95:49-55.

20. FURLONG, MJ, PELL, JK (2001). Horizontal transmission of entomopathogenic fungi by the diamondback moth. Biol. Control, 22:288-299.

21. GHAZAVI, M, AVAND-FAGHIH, A (2002). Isolation of two entomopathogenic fungi on red palm weevil, Rhynchophorus ferrugineus (Olivier) (Col., Curculionidae) in Iran. Appl. Entomol. Phytopathol., 9:44-45.

22. GIBLIN-DAVIS, RM (2001). Borers of palms. in: Howard, F.W., Moore, D., Giblin-Davis, R.M. and Abad, R.G. [Eds.] Insects on Palms. CABI Publishing, Walling ford, UK.: 267-305.

23. GINDIN,G, LEVSKI, S, GLAZER, I, SOROKER, V (2006). Evaluation of the Entomopathogenic Fungi Metarhizium anisopliae and Beauveria bassiana against the Red Palm Weevil Rhynchophorus ferrugineus, Phytoparasitica, 34(4):370-379.

24. GLARE TR, PLACET, C, NELSON, TL, REAY, SD (2002). Potential of Beauveria and Metarhizium as control agents of pinhole borers (Platypus spp.): 73-79.

25. GOTHANDAPANI S, BOOPALAKRISHANAN G, PRABHAKARAN N, CHETHANA BS, ARAVINDHAN M, SARAVANAKUMAR M, GIRIJA GANESHAN (2015). Evaluation of entomopathogenic fungus against Alternaria porri (Ellis) Causing purple blotch disease of onion Arch phytopathol pfl, 2015, $48,135$.

26. HU C, LAN YQ, QU JH, HU XX,WANG AM, (2006). $\mathrm{Ag} / \mathrm{Ag} \mathrm{Br} / \mathrm{Ti} \mathrm{O}_{2}$ visible light photo catalyst for destruction of azodyes and bacteria. J. physical chem, B $110,4066$.

27. IHARA, F, TOYAMA, M, SATO, T (2003). Pathogenicity of Metarhizium anisopliae to the chestnut weevil larvae under laboratory and field conditions. Appl. Entomol. Zool. 38:461-465.

28. JAYASEELAN C, RAHUMAN AA, RAJAKUMAR G, VISHNU KIRTHI A, SANTHOSHKUMAR T, MARIMUTHU S, BAGAVAN A, KAMARAJ C, ZAHIR AA, ELANGO G (2011). Synthesis of pediculocidal and larvicidal silver nanoparticles by leaf extract from heartleaf moonseed plant, Tinospora cordifolia Miers. Parasitol Res 109:185-194.

29. KAAKEH W (2005). Longevity, fecundity, and fertility of the red palm weevil, Rhynchophorus ferrugineus Olivier (Coleoptera: Curculionidae) on natural and artificial diets. Emirates Journal Agriculture Science 17:23-33.

30. KHAN, A, GANGAPERSAD, G (2001). Comparison of the effectiveness of threeentomopathogenic fungi in the management of the banana borer weevil, Cosmopolites sordidus (Germar) (Coleoptera: Curculionidae). Int. Pest Control, 2001, 43:208-213.

31. MOHAMED ABDEL-RAHEEM (2019). Entomopathogenic Fungus, Beauveria bassiana, Lambert Academic Publishing P148. https://www.morebooks.shop/ $\mathrm{gb} / \mathrm{search}$ utf8=\%E2\%9C\%93\&q=978-613-9-44933-0

32. MOHAMED ABDEL-RAHEEM, LAILA ALI M. ALSHURAYM, LAMYA AHMED AL-KERIDIS (2016). Date Palm Pests and Their Control, Lambert Academic Publishing, Pp. 76. https://www.morebooks.de/store/ de/book/date-palm-pests-and-their-control/isbn/978-3659-97440-3

33. MOHAMED ABDEL-RAHEEM, NAGLAA REYAD, IBRAHIM ABD EL-RAHMAN (2018). Entomopathogenic Fungi, Effective, Safe and Cheap Applications, Lambert Academic Publishing, p. 80. https://www. morebooks.de/store/us/book/entomopathogenic-fungi,effective,-safe-and-cheap-applications/isbn/978-613-985211-6

34. MOHAMED ABDEL-RAHEEM, SADEK SALEM and AHMED ABD EL- SALAM (2019). Red Palm Weevil, Rhynchophorus ferrugineus and Their Control, Lambert Academic Publishing, p. 188. https://www. morebooks.de/gb/search?utf8=\%E2\%9C\%93\&q=978620-0-23387-5

35. MONIR M. EL HUSSEINI (2019). Efficacy of the fungus Beauveria bassiana (Balsamo) Vuillemin on the red palm weevil Rhynchophorus ferrugineus Olivier (Coleoptera: Curculionidae) larvae and adults under laboratory conditions, Egyptian Journal of Biological Pest Control, 29:58, https://doi.org/10.1186/s41938019-0155-3

36. MOONJUNG, C, KYOUNG-HWAN S, JYONGSIK J. (2010). Plasmonic photocatalytic system using silver chloride/ silver nano structures under visible light. J. colloid Interface Sci, 2010, 341, 83.

37. NADAF, NY, KANASE, SS (2016). Bio synthesis of gold nanoparticles by Bacillus molisflavi and its potential in catalytic dye degradation, Arab J. Chem, Article in Press.

38. NAJI MORDI N. AL-DOSARY, SHOKI AL-DOBAI, JOSE ROMENO FALEIRO (2016). Review on the management of red palm weevil Rhynchophorus ferrugineus Olivier in date palm Phoenix dactylifera L, Emirates Journal of Food and Agriculture. 2016. 28(1): 34-44.

39. NAVROTSKY, A (2000). Technology and applications Nano materials in the environment, agriculture, and technology (NEAT). J Nano part Res, 2, 321.

40. NICOLA FRANCESCA, ANTONIO ALFONZO, GABRIELLA LO VERDE, LUCA SETTANNI, MILKO SINACORI, PAOLO LUCIDO AND GIANCARLO MOSCHETTI (2015). Biological activity of Bacillus spp. evaluated on eggs and larvae of red palm weevil Rhynchophorus ferrugineus, Ann Microbiol (2015) 65:477-485.

41. NISHA, C, BHAWONA, P, FULEKAR, MH (2017). Antimicrobial Potential of Green synthesized silver nanoparticles using sida acuta leaf extract, Vano Sci. Nano Technol, 11. 111. 
42. OWNLEY BH, GRIFFIN MR, KLINGEMAN WE, GWINN KD, MOULTON JK, PEREIRA RM (2008). Beauveria bassiana: Endophytic colonization and plant disease control. J Invertebr pathol, 98, 267.

43. PRAKASH D, MAHALE V, BANKAR A, NAWANI N, ZINJARDE S, KAPADNIS B (2013). Bio synthesis of colloidal gold nano particles by Streptomyces sp NK52 and its anti -lipid peroxidation activity. Indian J Exp Biol, 51, 969.

44. PRANEEHDEVI, T, KULANTHAIVEL, S, KAMIL, D, BORAH, J L, PRATHAKARAN, N, SRINIVASA, N (2013). Bio synthesis of silver nanoparticles from Trichoderma species, India J. Exp. Biol., 51, 543.

45. QUESADA-MORAGA, E, SANTOS-QUIROS, R, VALVERDE-GARCIA, P, SANTIAGO-ALVAREZ, C (2004). Virulence, horizontal transmission, and sublethal reproductive effects of Metarhizium anisopliae (anamorphic fungi) on the German cockroach (Blattodea: Blattellidae). J. Invertebr. Pathol. 87:51-58.

46. SALAMA HS, FODA MS, EL-BENDARY MA, ABDEL-RAZEK A (2004). Infection of red palm weevil, Rhynchophorus ferrugineus, by spore-forming bacilli indigenous to its natural habitat in Egypt. J Pest Sci 77(1):27-32.

47. Salem SA; Abd El-Salam, AME, El-Kholy MY (2016) Field Evaluation of Red Palm Weevil Rhynchophorus ferrugineus Oliv. (Coleoptera: Curculionidae) Responses to its Fermenting Date Tree Volatiles. International Journal of ChemTech Research. 9(5):12-17.

48. SHAIJU-SIMON, KUMAR, RK, GOKULAPALAN, C (2003). Occurrence of Beauveria sp. on red palm weevil, Rhynchophorus ferrugineus (Oliv.) of coconut. Insect Environ. 9:66-67.

49. SHAMSELDEAN, MM (2004). Laboratory trials and field applications of Egyptian and foreign entomopathogenic nematodes used against the red palm weevil, Rhynchophorus ferrugineus Oliv. Int. J. Nematol. 2004, 14:44-55.
50. SOROKER, V, BLUMBERG, D, HABERMAN, A, HAMBURGER-RISHARD, M, RENEH, S, TALEBAEV, S (2005). Current status of red palm weevil infestation in date palm plantations in Israel. Phytoparasitica, 2005, 33:97-106.

51. SUBHA PK, ESTHER RM, GUNASEELI R, HUSSAIN MM (2017). Extracllular synthesis of silver nanoparticles by the fungus Emericella nidulans EV4 and its application. Indian J Exp Biol, 55, 262.

52. SUNDARAVADIVELAN C, PADMANABHAN MN (2014). Effect of mycosynthesized silver nanoparticles from filtrate of Trichoderma harzianum against larvae and pupa of dengue vector Aedes aegypti L. Environ Sci Pollut Res 21:4624-4633.

53. TEFERA, T, PRINGLE, K.L. (2003). Food consumption by Chilo partellus (Lepidoptera: Pyralidae) larvae infected with Beauveria bassiana and Metarhizium anisopliae and effects of feeding natural versus arti_cial diets on mortality and mycosis. J. Invertebr. Pathol., 84:220-225.

54. THOMAS, MB, BLANFORD, S, LOMER, CJ (1997). Reduction of feeding by the variegated grasshopper, Zonocerus variegatus, following infection by the fungal pathogen Metarhizium avoviride. Biocontrol Sci., Technol. 3:327-334.

55. YASUR J, USHA RANI P (2015). Lepidopteran insect susceptibility to silver nanoparticles and measurement of changes in their growth, development and physiology. Chemosphere 124:92-102

56. ZAKI, FN AND ABDEL-RAHEEM, MA (2010). Using of Entomopathogenic fungi and insecticide against some insect pests attacking peanuts and sugar beet. Archives of phytopathology and plant protection, 43(18):1819-1828.

57. ZONORODIAM, K, POURSHAHID, S, SADATSHARIFI, A (2016). Bio synthesis and characterization of silver nanoparticles by Aspergillus species, Bio Med Res Int, 1. 